\title{
Synthesis, characterization, and stability of iron (III) complex ions possessing phenanthroline-based ligands
}

\author{
Shawnt Tosonian ${ }^{*}$, Charles J. Ruiz ${ }^{*}$, Andrew Rios, Elma Frias, Jack F. Eichler ${ }^{\#}$
}

Department of Chemistry, University of California, Riverside, Riverside, USA

Email: ${ }^{\text {eichler@ucr.edu }}$

Received 3 November 2012; revised 2 December 2012; accepted 14 December 2012

\begin{abstract}
It has previously been demonstrated that phenanthroline-based ligands used to make gold metallotherapuetics have the ability to exhibit cytotoxicity when not coordinated to the metal center. In an effort to help assess the mechanism by which these ligands may cause tumor cell death, iron binding and removal experiments have been considered. The close linkage between cell proliferation and intracellular iron concentrations suggest that iron deprivation strategies may be a mechanism involved in inhibiting tumor cell growth. With the creation of iron (III) phen complexes, the iron binding abilities of three polypyridal ligands [1,10-phenanthroline (phen), 2,9-dimethyl-1, 10-phenanthroline ( ${ }^{\text {methyl }}$ phen), and 2,9-di-sec-butyl-1, 10-phenanthroline ( ${ }^{\text {sec-butyl }}$ phen)] can be tested via a competition reaction with a known iron chelator. Therefore, iron (III) complexes possessing all three ligands were synthesized. Initial mass spectrometric and infrared absorption data indicate that iron (III) tetrachloride complex ions with protonated phen ligands $\left({ }^{\mathrm{R}}\right.$ phen $\left.\mathrm{H}^{+}\right)$were formed: [phenH] $\left[\mathrm{FeCl}_{4}\right]$, [ ${ }^{\text {methyl }}$ phenH][FeCl $\left.{ }_{4}\right], \quad{ }^{\text {sec-butyl }}$ phenH] $\left[\mathrm{FeCl}_{4}\right]$. UV-Vis spectroscopy was used to monitor the stability of the complex ions, and it was found that the ${ }^{\text {sec-butyl }}$ pheniron complex was more stable than the phen and methyl phen analogues. This was based on the observation that free ligand was observed immediately upon the addition of EDTA to the $\left[\mathrm{phenH}^{2}\left[\mathrm{FeCl}_{4}\right]\right.$ and [ ${ }^{\text {methyl }}$ phenH] $\left[\mathrm{FeCl}_{4}\right]$ complex ions.
\end{abstract}

Keywords: Polypyridyl Ligands; Phenanthroline; Iron (III); Complex Ions

\section{INTRODUCTION}

Cancer is the 2nd leading cause of death in the United States. Though a wide variety of organic-based molecular compounds have been used to treat tumors, the metallotherapy cisplatin is one of the most successful anti-

\footnotetext{
"These authors contributed equally to this work
}

\#Corresponding author. cancer drugs. Despite its success, cisplatin therapy has several drawbacks, including the development of resistance to the drug by tumors and the occurrence of severe side-effects during treatment [1]. It is well known that gold (III) complexes are potential alternatives to the platinum (II) based drugs [2]. Even though gold (III) complexes with polypyridyl based ligands [e.g., 1,10phenanthroline (phen), 2,2'-bipyri-dine (bipy), and 2,2'6 ',2"-terpyridine (terpy)] have shown promise as anticancer agents, it has also been shown that the polypyridyl ligands can have antitumor activity on their own; therefore the antiproliferative properties of the ligands must be considered when evaluating the antitumor activity of the corresponding metal-based complexes $[1,3,4]$.

We have previously reported the synthesis of a gold (III) complex bearing a 2,9-di-sec-butyl-1,10-phenanthroline (sec-butyl phen) ligand $\left\{\left[\left({ }^{\text {sec-butyl }}\right.\right.\right.$ phen) $\left.\left.\mathrm{AuCl}_{3}\right]\right\} \quad$ [5]. The anti-tumor activity of this gold complex compound is currently being studied, therefore it is desired to determine the potential activity of the ${ }^{\text {sec-butyl }}$ phen ligand. It has been previously hypothesized that chelating ligands can impact tumor cell death via iron depletion [6]. Additionally, Satterfield and Brodbelt reported that alkyl substituents on phenanthroline ligands have an impact on metal binding [7], and this data predicts that ${ }^{\text {sec-butyl }}$ phen should exhibit stronger metal binding than unsubstituted phen. To test whether alkyl substituted phenanthroline based ligands have different iron binding abilities, we synthesized and characterized iron complex ions with a series of phenanthroline-based ligands [phen, ${ }^{\text {sec-butyl }}$ phen, and 2,9-dimethyl-1,10-phenanthroline ( ${ }^{\text {methyl }}$ phen)], and evaluated the relative stability of these three complex ions.

\section{MATERIALS AND METHODS}

\subsection{General Experimental Procedures}

sec-butyl phen was synthesized according to a previously published protocol [8]; phen and ${ }^{\text {methyl }}$ phen were purchased from Sigma-Aldrich and used without purification, as were all other reagents and solvents used in the 
course of characterizing the iron (III) complex ions. UVVis spectra were recorded on a Varian Cary 50 UV-Vis spectrophotometer, and IR spectra were obtained using a Perkin Elmer Spectrum One FT-IR Spectrophotometer fitted with a Universal ATR sampling accessory. Mass spectrometric analyses were performed using a Waters GCT (2008) high resolution mass spectrometer, using Electrospray Ionization (ESI) and Liquid Injection Field Desorption Ionization (LIFDI) techniques.

\subsection{Synthesis of $[\mathrm{phenH}]\left[\mathrm{FeCl}_{4}\right] \cdot 2 \mathrm{H}_{2} \mathrm{O}(1)$}

The iron (III) phen complex was synthesized using a previously published protocol [9]. A solution of $0.130 \mathrm{~g}$ $\mathrm{FeCl}_{3}(0.802$ mmole) in a $10 \mathrm{M}$ aqueous $\mathrm{HCl}(10 \mathrm{~mL})$ was added to a $150 \mathrm{~mL}$ reaction flask. To this was added $0.145 \mathrm{~g}$ (0.802 mmole) of 1,10-phenanthroline, which was dissolved in $10 \mathrm{~mL}$ of $\mathrm{HCl}$. The ligand solution was added dropwise, upon which an orange color was observed. The solution was stirred overnight at room temperature, and an orange precipitate was formed. The solid was filtered and dried in vacuo, and $0.224 \mathrm{~g}$ of product was obtained after the solid was recrystallized from ethanol $\left(77.3 \%\right.$ yield). Melting point: $298-301^{\circ} \mathrm{C}$. UV-Vis $\left[\lambda_{\max } / \mathrm{nm} \quad\left(\varepsilon / \mathrm{M}^{-1} \cdot \mathrm{cm}^{-1}\right)\right]: \quad 230 \quad(28,847), \quad 270$ $(23,812), 320$ (6623), $366(6608)$. IR $\left[\mathrm{v}_{\max } / \mathrm{cm}^{-1}\right]: 3350$ (NH); 3051 (CH aromatic); 2000 - 1600 (aromatic overtones); $1611 ; 1605 ; 1,580,1517 ; 1345 ; 855$. Mass spec (LIFDI): mo- lecular ion; $\mathrm{m} / \mathrm{z}=306$; compound $1-$ $2 \mathrm{Cl}^{-}\left\{\left[(\right.\right.$phen $\left.\left.) \mathrm{FeCl}_{2}\right]+=306 \mathrm{amu}\right\}$.

\subsection{Synthesis of [ ${ }^{\text {methyl }}$ phenH] $\left[\mathrm{FeCl}_{4}\right]$ (2)}

Compound 2 was prepared in an analogous fashion to compound 1 using $0.130 \mathrm{~g}(0.802$ mmole $)$ of $\mathrm{FeCl}_{3}$ and $0.174 \mathrm{~g}$ (0.802 mmole) 2,9-dimethyl-1,10-phenanthroline. A yellow precipitate was isolated and recrystallized from ethanol $(0.283 \mathrm{~g}, 89.1 \%$ yield). Melting point: 180 $185^{\circ} \mathrm{C}$. UV-Vis $\left[\lambda_{\max } / \mathrm{nm}\left(\varepsilon / \mathrm{M}^{-1} \cdot \mathrm{cm}^{-1}\right)\right]: 225(31,119)$, $280(27,475), 317(10,306), 364(6318)$. IR $\left[\mathrm{v}_{\max } / \mathrm{cm}^{-1}\right]$ : $3375(\mathrm{NH}) ; 3051$ ( $\mathrm{CH}$ aromatic); 2904 (CH aliphatic); 2000 - 1600 (aromatic overtones), 1680; 1625; 1600; $1500 ; 1345 ; 865$. Mass spec (LIFDI): molecular ion; $\mathrm{m} / \mathrm{z}$ $=334$; compound $2-2 \mathrm{Cl}^{-}\left\{\left[\left({ }^{\text {methyl }}\right.\right.\right.$ phen $\left.) \mathrm{FeCl}_{2}\right]+=334$ $\mathrm{amu}\}$.

\subsection{Synthesis of [ ${ }^{\text {sec-butyl }}$ phenH][$\left[\mathrm{FeCl}_{4}\right]$ (3)}

Compound 3 was prepared as described for compound 1 using $0.130 \mathrm{~g}(0.802 \mathrm{mmole})$ of $\mathrm{FeCl}_{3}$ and $0.235 \mathrm{~g}(0.802$ mmole) 2,9-di-sec-butyl-1,10-phenanthroline. A brownred solid was isolated and recrystallized from ethanol ( $0.190 \mathrm{~g}, 50.1 \%$ yield). Melting point: sample decomposition was observed over a wide temperature range above $150^{\circ} \mathrm{C}$. UV-Vis $\left[\lambda_{\max } / \mathrm{nm}\left(\varepsilon / \mathrm{M}^{-1} \mathrm{~cm}^{-1}\right)\right]: 225(46,278), 270$
(29,480), 317 (10,306), 364 (8168). IR $\left[\mathrm{v}_{\max } / \mathrm{cm}^{-1}\right]: 3200$ (NH); 3068 (CH aromatic); 2962 (CH aliphatic); 2000 1600 (aromatic overtones); 1622; 1605; 1570, 1527; 1342; 855. Mass spec (LIFDI): molecular ion; $\mathrm{m} / \mathrm{z}=$ 418; compound $3-2 \mathrm{Cl}^{-}\left\{\left[{ }^{\text {sec-butyl }}\right.\right.$ phen $\left.) \mathrm{FeCl}_{2}\right]+=418$ $\mathrm{amu}\}$.

\subsection{EDTA Competition Reaction}

The EDTA binding reaction was modeled on a previously published protocol [10]. Stock solutions were prepared in $5 \mathrm{~mL}$ of acetonitrile using $10.0 \mathrm{mg}$ of the phenanthroline iron complexes $\left\{2.94 \times 10^{-5} \mathrm{~mol}[\mathrm{phenH}]\right.$ $\left[\mathrm{FeCl}_{4}\right], 2.51 \times 10^{-5} \mathrm{~mol}$ of [ ${ }^{\text {methyl }}$ phenH] $\left[\mathrm{FeCl}_{4}\right], 2.12 \times$ $10^{-5} \mathrm{~mol}\left[{ }^{\text {sec-butyl }}\right.$ phenH] $\left.\left[\mathrm{FeCl}_{4}\right]\right\}$ to yield concentrations of: $0.00588 \mathrm{M}$ of [phen $\mathrm{H}]\left[\mathrm{FeCl}_{4}\right], 0.00503 \mathrm{M}$ of [ phen $\mathrm{H}]\left[\mathrm{FeCl}_{4}\right]$, and $0.00420 \mathrm{M}$ of $\left[{ }^{\text {sec-butyl }}\right.$ phenH] $\left[\mathrm{FeCl}_{4}\right]$. These stock solutions were then diluted in acetonitrile to create solutions with a final concentration of $3.43 \times 10^{-5}$ M. A $0.028 \mathrm{M}$ solution of EDTA in distilled water was prepared for the binding experiment. The EDTA solution was then added to the iron (III) complex ions in a 20:1 EDTA:iron molar ratio, and the UV-Vis absorption spectra were collected every minute for thirty minutes.

\section{RESULTS AND DISCUSSION}

\subsection{Synthesis}

The phen-iron complexes were synthesized by combining the phenanthroline ligand with $\mathrm{FeCl}_{3}$ in a 1:1 molar ratio, in the presence of $10 \mathrm{M}$ aqueous hydrochloric acid and water (Scheme 1). The resulting precipitates were then filtered, dried under vacuum, and recrystallized from ethanol to obtain the final complex ions. The products obtained were the complex ions comprised of the protonated phen ligand cation $\left({ }^{\mathrm{R}}\right.$ phenH $\left.{ }^{+}\right)$and the $\mathrm{FeCl}_{4}{ }^{-}$ anion. It is noted that previous work describing a similar synthetic protocol reported the formation of an iron (III) phen complex where the ligand was directly coordinated to the iron (III) metal center. However, the yield of this compound was extremely low, and was likely a minor side product in the reaction [9]. Khavasi and coworkers also report that the complex ion possessing $[\mathrm{phenH}]^{+}$ and $\left[\mathrm{FeCl}_{4}\right]^{-}$was isolated after the reaction between phen and $\mathrm{FeCl}_{3}$ in hot aqueous solution [11]. Other studies do demonstrate that complexes possessing direct coord-

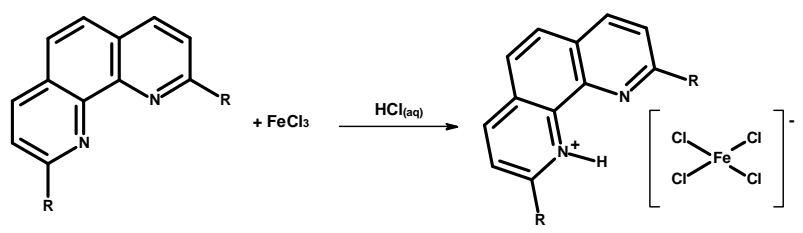

Scheme 1. Synthesis of compounds $1-3 . \mathrm{R}=\mathrm{H}$ (1), $-\mathrm{CH}_{3}$ (2), and $-\mathrm{CH}\left(\mathrm{CH}_{3}\right) \mathrm{CH}_{2} \mathrm{CH}_{3}$ (3). 
ination between phen and iron (III) can be isolated, however these are obtained by reacting equimolar amounts of phen with $\mathrm{FeCl}_{3}$ in non-aqueous methanol [12], or by refluxing the $[\mathrm{phenH}]\left[\mathrm{FeCl}_{4}\right]$ complex ion in DMSO solvent [13].

\subsection{Infrared Spectroscopy}

IR results for compounds 1-3 show a single resonance at $3350 \mathrm{~cm}^{-1}, 3375 \mathrm{~cm}^{-1}$, and $3200 \mathrm{~cm}^{-1}$, respectively, indicating the presence of a protonated secondary amine and thereby providing additional evidence that the complex ions proposed in Scheme 1 were obtained. The presence of the ${ }^{\mathrm{R}}$ phen ligands is confirmed by the $\mathrm{C}-\mathrm{H}$ aromatic resonances at $3051 \mathrm{~cm}^{-1}$ (1), $3051 \mathrm{~cm}^{-1}$ (2), and $3068 \mathrm{~cm}^{-1}$ (3), as well as C-N bands at $1345 \mathrm{~cm}^{-1}$ (1), $1345 \mathrm{~cm}^{-1}$ (2), and $1342 \mathrm{~cm}^{-1}$ (3). Though the previous reports of the $[\mathrm{phenH}]\left[\mathrm{FeCl}_{4}\right]$ complex ion do not provide IR data for the $\mathrm{N}-\mathrm{H}$ stretch of the protonated ligand, previous reports with similar $\left[{ }^{\mathrm{R}}\right.$ phenH] $]\left[\mathrm{AuCl}_{4}\right]$ complex ions also indicate that the $\mathrm{N}-\mathrm{H}$ stretch for the protonated ${ }^{R}$ phen ligands is observed in the IR spectrum (at approximately $3180 \mathrm{~cm}^{-1}$ ) [5].

\subsection{Mass Spectrometry}

In addition to the elemental analysis and IR data, mass spectrometry indicates that $\left[{ }^{\mathrm{R}}\right.$ phenH] $]\left[\mathrm{FeCl}_{4}\right]$ complex ions were isolated. This is evidenced by the fact that electrospray ionization (ESI) only produced the individual $\left[{ }^{\mathrm{R}} \text { phenH }\right]^{+}$ion (observed in positive ion mode), or the $\left[\mathrm{FeCl}_{4}\right]^{-}$ion (observed in negative ion mode; see Supplemental Data Figure 1 for representative data). In order to determine if the complex ions could be ionized without breaking the ion pair, Liquid Introduction Field Desorption Ionization (LIFDI) was subsequently used. LIFDI is known for being a soft ionization technique [14], thus the complex ions were expected to remain associated during the ionization process. Upon ionization via LIFDI positively charged molecular ions composed of $\left[\left({ }^{\mathrm{R}} \text { phen }\right) \mathrm{FeCl}_{2}\right]^{+}$fragments, formed upon the loss of two chloride ligands, were indeed detected (see Figure 1 and Supplemental Data Figures 2 and 3). It is also noted that compounds 2 and 3 exhibited fragment peaks in the LIFDI mode corresponding to the $\left[^{\mathrm{R}} \mathrm{phenH}\right]^{+}$protonated ligands, further corroborating the final structural assignments for this class of compounds (compound 1 had a $\left[(\text { phen }) \mathrm{FeCl}_{2}\right]^{+}$fragment with $\mathrm{m} / \mathrm{z}=306$; compound 2 had a $\left[\left({ }^{\text {methyl }} \text { phen }\right) \mathrm{FeCl}_{2}\right]^{+}$fragment with $\mathrm{m} / \mathrm{z}=334$ and a $\left[{ }^{\text {methyl }} \text { phenH }\right]^{+}$fragment with $\mathrm{m} / \mathrm{z}=209$; compound 3 had a $\left[\left(^{\text {sec-butyl }} \text { phen) } \mathrm{FeCl}_{2}\right]^{+}\right.$fragment with $\mathrm{m} / \mathrm{z}=418$ and a $\left[{ }^{\text {sec-butyl }} \text { phenH }\right]^{+}$fragment with $\mathrm{m} / \mathrm{z}=293$ ).

\subsection{Ultraviolet Visible (UV-Vis) Spectroscopy}

Compounds 1-3 were characterized by UV-Vis spec-

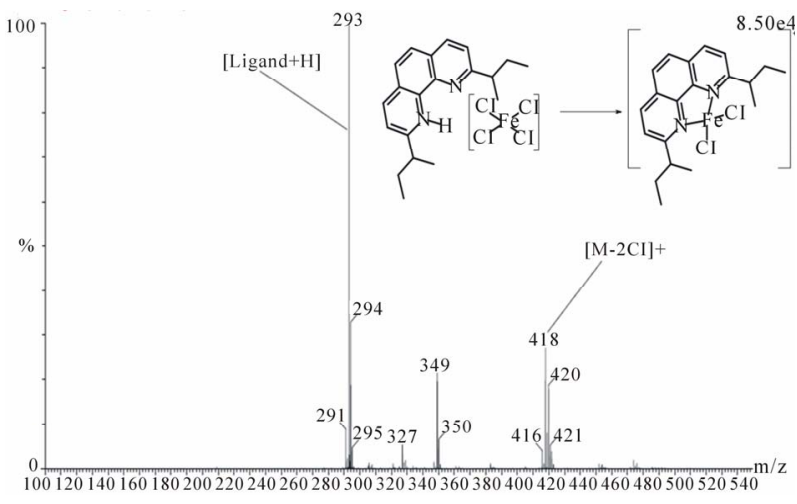

Figure 1. Representative LIFDI mass spectrometry data for the $\left[{ }^{\mathrm{R}}\right.$ phen $\left.\mathrm{H}\right]\left[\mathrm{FeCl}_{4}\right]$ complex ions. The spectrum shown is for the $\left[{ }^{\text {sec-butyl }}\right.$ phenH] $\left[\mathrm{FeCl}_{4}\right]$ complex ion (compound 3 ). The molecular ion at $\mathrm{m} / \mathrm{z}=418$ corresponds to the complex ion after the loss of two $\mathrm{Cl}^{-}$ligands; the fragment peak at $\mathrm{m} / \mathrm{z}=293$ corresponds to the protonated ${ }^{\text {sec-butyl }}$ phen ligand.

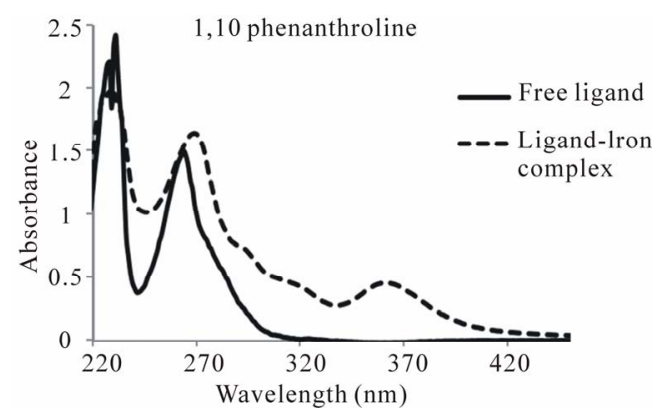

(a)

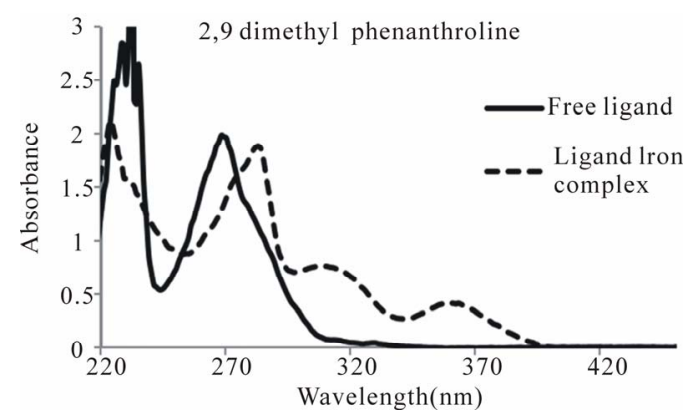

(b)

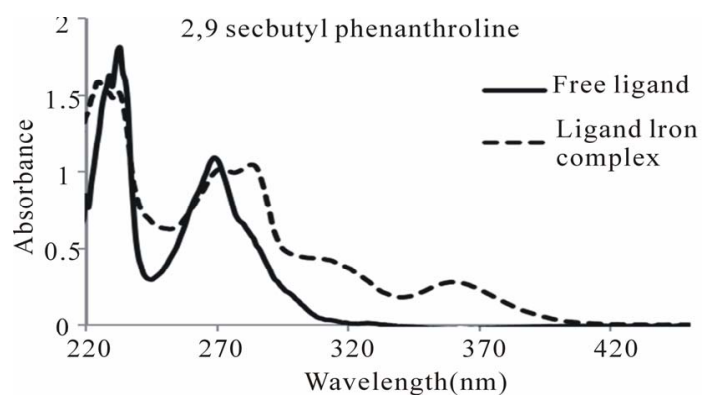

Figure 2. Uv-Vis absorbance spectra for the $\left[{ }^{\mathrm{R}}\right.$ phenH] $\left[\mathrm{FeCl}_{4}\right]$ complex ions and free ${ }^{\mathrm{R}}$ phen ligands. (a) ${ }^{\mathrm{R}}$ phen and [phenH] $\left[\mathrm{FeCl}_{4}\right](1)$; (b) ${ }^{\text {methyl }}$ phen and [ ${ }^{\text {methyl }}$ phenH] $\left[\mathrm{FeCl}_{4}\right](2) ;(\mathrm{c}){ }^{\text {sec-butyl }}$ phen and $\left[{ }^{\text {sec-butyl }}\right.$ phenH) $]\left[\mathrm{FeCl}_{4}\right]$ (3). 


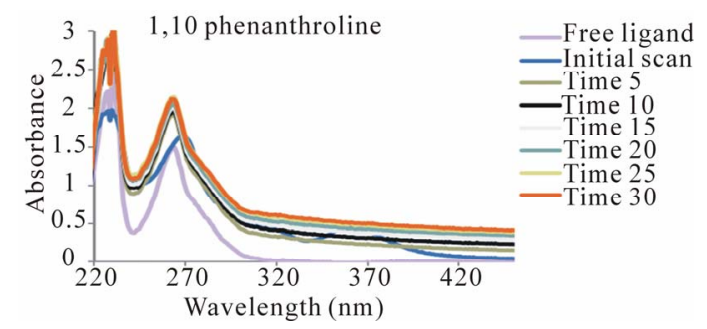

(a)

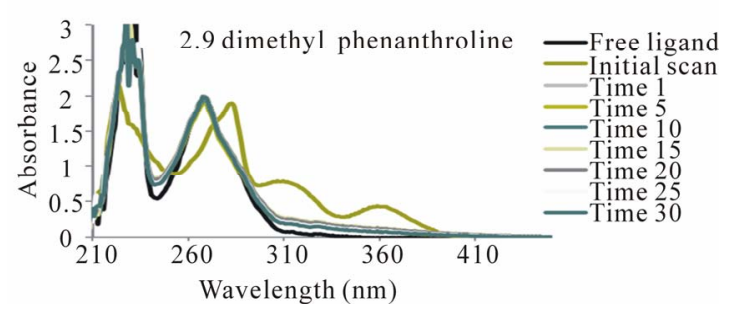

(b)

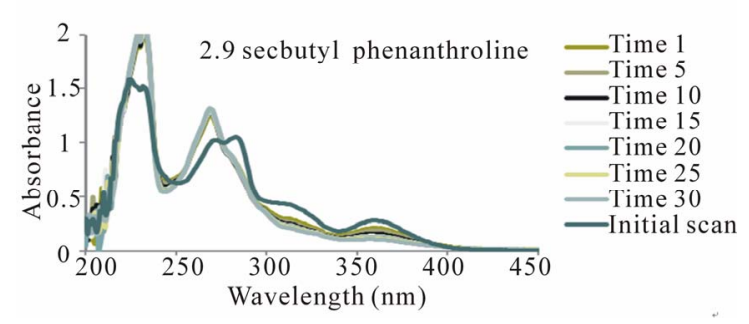

(c)

Figure 3. EDTA stability monitored by UV-Vis absorbance. Spectra are shown at 5-minute intervals after the addition of EDTA in a 20:1 molar ratio. (a) [phenH] $\left[\mathrm{FeCl}_{4}\right]$ (1); (b) $\left[{ }^{\text {methyl }}\right.$ phenH] $\left[\mathrm{FeCl}_{4}\right]$ (2); (c) $\left[{ }^{\text {sec-butyl }}\right.$ phenH $\left.)\right]\left[\mathrm{FeCl}_{4}\right](3)$.

troscopy. Although direct coordination of the ligand with the iron metal center was not achieved using the synthetic protocol described herein, the complex ions have absorption spectra that confirm the presence of both the protonated ${ }^{\mathrm{R}}$ phen ligand and $\left[\mathrm{FeCl}_{4}\right]^{-}$anion. In fact, in the absence of the elemental analysis, IR, and mass spectrometry data, the absorption profiles for the $\left[{ }^{\mathrm{R}}\right.$ phenH] $\left[\mathrm{FeCl}_{4}\right]$ complex ions could be misinterpreted as evidence for direct metal binding of the phen ligand; the $\pi$ $\rightarrow \pi^{*}$ charge transfer of the ligand red shifts from 260 $270 \mathrm{~nm}$ for the free ligand $(265 \mathrm{~nm}$ for phen; $270 \mathrm{~nm}$ for ${ }^{\text {methyl }}$ phen; $270 \mathrm{~nm}$ for ${ }^{\text {sec-butyl }}$ phen) to $270-290 \mathrm{~nm}$ in the complex ions $\left(275 \mathrm{~nm}\right.$ for $[\mathrm{phenH}]\left[\mathrm{FeCl}_{4}\right] ; 285 \mathrm{~nm}$ for $\left[{ }^{\text {methyl }}\right.$ phenH] $\left[\mathrm{FeCl}_{4}\right] ; 285 \mathrm{~nm}$ for [ ${ }^{\text {sec-butyl }}$ phenH] $\left[\mathrm{FeCl}_{4}\right]$ ), and two absorption bands assigned as a ligand-to-metal charge transfer are observed at approximately $315-320$ $\mathrm{nm}$ and $360-370 \mathrm{~nm}$ (see Figure 2). The red shift in the $\pi \rightarrow \pi^{*}$ charge transfer hasbeen previously reported as a result of the phen ligand coordinated to the metal iron, as have the presence of similar ligand-to-metal charge transfer bands in phenanthroline iron (III) chloride com- plexes [11]. The similarity between UV-Vis absorption spectra for complex ions possessing protonated phen ligands and coordination complexes possessing coordinated phen ligands has been noted before, specifically for $\left[{ }^{\mathrm{R}}\right.$ phenH $]\left[\mathrm{AuCl}_{4}\right]$ complex ions and $\left[\left({ }^{\mathrm{R}} \mathrm{phen}\right) \mathrm{AuCl}_{3}\right]$ coordination complexes [5].

\subsection{EDTA Stability Studies}

Even though the ${ }^{\mathrm{R}}$ phen ligands did not directly coordinate to the iron (III) metal centers, competition binding experiments were carried out to determine if the substitution on the phen ligand might impact the stability of the $\left[\mathrm{FeCl}_{4}\right]+$ cation in solution. In order to test the stability of the complex ions, compounds 1-3 were treated with an excess of EDTA and the UV-Vis spectra monitored for a 30-minute period. The un-substituted $[\mathrm{phenH}]\left[\mathrm{FeCl}_{4}\right]$ complex ion (compound 1) and methyl substituted $\left[{ }^{\text {methyl }}\right.$ phenH] $\left[\mathrm{FeCl}_{4}\right]$ complex ion (compound 2) showed an immediate dissociation of the free ligand upon addition of EDTA, evidenced by the blue shift of the $\pi \rightarrow \pi^{*}$ charge transfer band, and the complexation of the iron (III) metal center, evidenced by the elimination of the ligand-to-metal charge transfer bands at $315-320 \mathrm{~nm}$ and $360-370 \mathrm{~nm}$ (see Figures 3(a) and (b)). The decomposition of compounds 1 and 2 in the presence of EDTA was essentially instantaneous, as these spectral changes were observed within the first minute upon adding the EDTA solution.

Conversely, the sec-butyl substituted [ ${ }^{\text {sec-butyl }}$ phenH] $\left[\mathrm{FeCl}_{4}\right]$ complex ion (compound 3) displayed behavior that was significantly different from the other two compounds in the series. Although the $\pi \rightarrow \pi^{*}$ charge transfer band immediately shifts back to the absorbance maximum observed in the free ligand, there is a gradual decrease in the ligand-to-metal charge transfer bands at approximately $320 \mathrm{~nm}$ and $370 \mathrm{~nm}$ (see Figure 3(c)). These results suggest that the ${ }^{\text {sec-butyl }}$ phen ligand stabilizes the $\left[{ }^{\mathrm{R}}\right.$ phenH] $\left[\mathrm{FeCl}_{4}\right]$ complex ion. This could potentially be attributed to the fact that ${ }^{\text {sec-butyl }}$ phen is a stronger base than phen and ${ }^{\text {methyl }}$ phen, thereby inhibiting the deprotonation of the ligand by EDTA. However, given the fact that the ligand-to-metal charge transfer bands are eliminated more slowly over time compared to the [phenH] $\left[\mathrm{FeCl}_{4}\right]$ and $\left[{ }^{\text {methyl }}\right.$ phenH $]\left[\mathrm{FeCl}_{4}\right]$ complex ions, it appears that the ${ }^{\text {sec-butyl }}$ phen ligand may provide some protection to iron (III) metal center. Satterfield and Brodbelt have previously quantified the ability of substituted phen ligands to bind metal cations, and their studies indicate that the larger sec-butyl substituent on the 2,9-positions of the phen ligand enhance metal binding [7]. Thus, the fact the ${ }^{\text {sec-butyl }}$ phen ligand provides some protection of the iron (III) metal center is not completely unexpected. The LIFDI mass spectrometry data seem to provide fur- 
ther evidence of an interaction between the ${ }^{\mathrm{R}}$ phen ligands and iron (III) metal center in solution, given the fact that the molecular ions for compounds 1-3 are comprised of a $\left[\left({ }^{\mathrm{R}}\right.\right.$ phen $\left.) \mathrm{FeCl}_{2}\right]+$ cation.

\section{SUMMARY}

It has been shown that reacting phen and 2,9-di-alkylsubstituted phen ligands with iron (III) chloride in the presence of aqueous acid results in the isolation of complex ions comprised of protonated ${ }^{\mathrm{R}}$ phen ligands and $\mathrm{FeCl}_{4}^{-}$anions. Even though direct coordination of the ${ }^{R}$ phen ligands was not observed, EDTA stability studies indicate that the $\left[{ }^{\text {sec-butyl }}\right.$ phenH] $]\left[\mathrm{FeCl}_{4}\right]$ complex ion (compound 3) is more stable than the unsubstituted phen and ${ }^{\text {methyl }}$ phen congeners, and LIFDI mass spectrometry analyses provide evidence of an interaction between the ${ }^{R}$ phen ligands and the iron (III) metal center in solution. Future work will be focused on developing a synthetic protocol that results in the direct coordination between sec-butyl phen ligand and iron (III) metal center, and then comparing its binding strength to the analogous phen and methylphen coordination complexes. Ultimately, this data will lend more insight about the potential role of sec-butyl phen as an iron chelator in the course of tumor cell antiproliferative studies.

\section{ACKNOWLEDGEMENTS}

The authors would like to acknowledge the UCR MARC U STAR program (funded by the NIH) for supporting EF during the summer of 2012, and the UCR STEM Pathways for supporting CR and AR during the summer of 2012. The authors would also like to thank the UCR High Resolution Mass Spectrometry facility for their work in completing the ESI and LIFDI mass spectrometry experiments (under NSF grant CHE-0742001).

\section{REFERENCES}

[1] Wein, A.N., Stockhausen, A.T., Hardcastle, K.I., Saadein, M.R., Peng, S., Wang, D. and Eichler, J.F. (2011) Tumor cytotoxicity of 5,6-dimethyl-1,10-phenanthroline and its corresponding gold (III) complex. Journal of Inorganic Biochemistry, 105, 663-668. doi:10.1016/i.jinorgbio.2011.01.006

[2] Sun, R. and Che, C. (2009) The anti-cancer properties of gold (III) compounds with dianionic porphyrin and tetradentate ligands. Coordination Chemistry Reviews, 253, 1682-1691. doi:10.1016/j.ccr.2009.02.017

[3] Messori, L., Abbate, F., Marcon, G., Orioli, P., Fontani, M., Mini, E., Mazzei, T., Carotti, S., O'Connell, T. and Zanello, P. (2000) Gold (III) complexes as potential antitumor agents: Solution chemistry and cytotoxic properties of some selected gold (III) compounds. Journal of $\mathrm{Me}$ dicinal Chemistry, 43, 3541-3548. doi:10.1021/jm990492u

[4] Cinellu, M.A., Maiore, L., Manassero, M., Casini, A.,
Arca, M., Fiebig, H.-H., Kelter, G., Michelucci, E., Pieraccini, G., Gabbiani, C. and Messori, L. (2010) $\left[\mathrm{Au}_{2}\right.$ $\left.\left(\text { phen }^{2 \mathrm{Me}}\right)_{2}(\mu-\mathrm{O})_{2}\right]\left(\mathrm{PF}_{6}\right)_{2}$, a novel dinuclear gold (III) complex showing excellent antiproliferative properties. ACS Medicinal Chemistry Letters, 1, 336-339.

[5] Hudson, Z.D., Sanghvi, C.D., Rhine, M.A., Ng, J.J., Bunge, S.D., Hardcastle, K.I., Macbeth, C. and Eichler, J.F. (2009) Synthesis and characterization of gold (III) complexes possessing 2,9-dialkylphenanthroline ligands: To bind or not to bind? Dalton Transactions, 28, 74737480. doi: $10.1039 / \mathrm{b} 823215 \mathrm{f}$

[6] Richardson D.R., Tran, E.H. and Ponka, P. (1998) The potential of iron chelators of the pyridoxal isonicotinoyl hydrazone class as effective antiproliferative agents. Blood, 86, 4295-4306.

[7] Satterfield, M. and Brodbelt, J.S. (2001) Relative binding energies of gas-phase pyridyl ligand/metal complexes by energy-variable collisionally activated dissociation in a quadrupole ion trap. Inorganic Chemistry, 40, 5393-5400. doi:10.1021/ic010356r

[8] Pallenberg, A.J., Koenig, K.S. and Barnhart, D.M., (1995) Synthesis and characterization of some copper (I) phenanthroline complexes. Inorganic Chemistry, 34, 28332840. doi:10.1021/ic00115a009

[9] Kulkarni, P., Padhye, S. and Sinn, E. (1998) Communication: The first well characterized $\mathrm{Fe}$ (phen) $\mathrm{Cl}^{3}$ complex: Structure of aquo mono(1,10-phenanthroline) iron (III) trichloride: [Fe (phen) $\left.\mathrm{Cl}^{3}\left(\mathrm{H}^{2} \mathrm{O}\right)\right]$. Polyhedron, 17, 26232626. doi:10.1016/S0277-5387(97)00515-9

[10] Hara, Y. and Akiyama, M. (2001) An iron reservoir model based on ferrichrome: Iron (III)-binding and metal (III)-exchange properties of tripodal monotopic and ditopic hydroxamate ligands with an 1-alanyl-l-alanyl-n-hydroxy- $\beta$-alanyl sequence. Journal of the American Chemical Society, 123, 7247-7256. doi:10.1021/ja003251g

[11] Khavasi, H.R., Amani, V. and Safari, N. (2008) (2,2'Biquinoline-2N,N')dichloridoiron(II). Zeitschrift für Kristallographie - New Crystal Structures, 223, 41-42.

[12] Eckenhoff, W.T., Biernesser, A.B. and Pintauer, T. (2012) Structural characterization and investigation of iron (III) complexes with nitrogen and phosphorus based ligands in atom transfer radical addition (ATRA). Inorganica Chimica Acta, 382, 84-95. doi:10.1016/j.ica.2011.10.016

[13] Amani, V., Nasser, S., Khavasi, H.R. and Mirzaei, P. (2007) Iron (III) mixed-ligand complexes: Synthesis, characterization and crystal structure determination of iron (III) hetero-ligand complexes containing 1,10-phenanthroline, 2,2'-bipyridine, chloride and dimethyl sulfoxide, $\left[\mathrm{Fe}(\mathrm{phen}) \mathrm{Cl}_{3}(\mathrm{DMSO})\right]$ and $\left[\mathrm{Fe}(\right.$ bipy $\left.) \mathrm{Cl}_{3}(\mathrm{DMSO})\right]$. Polyhedron, 26, 4908-4914. doi:10.1016/j.poly.2007.06.038

[14] Gomer, R. and Inghram, M.G. (1955) Applications of field ionization to mass spectrometry. Journal of the American Chemical Society, 77, 500. doi:10.1021/ja01607a096 

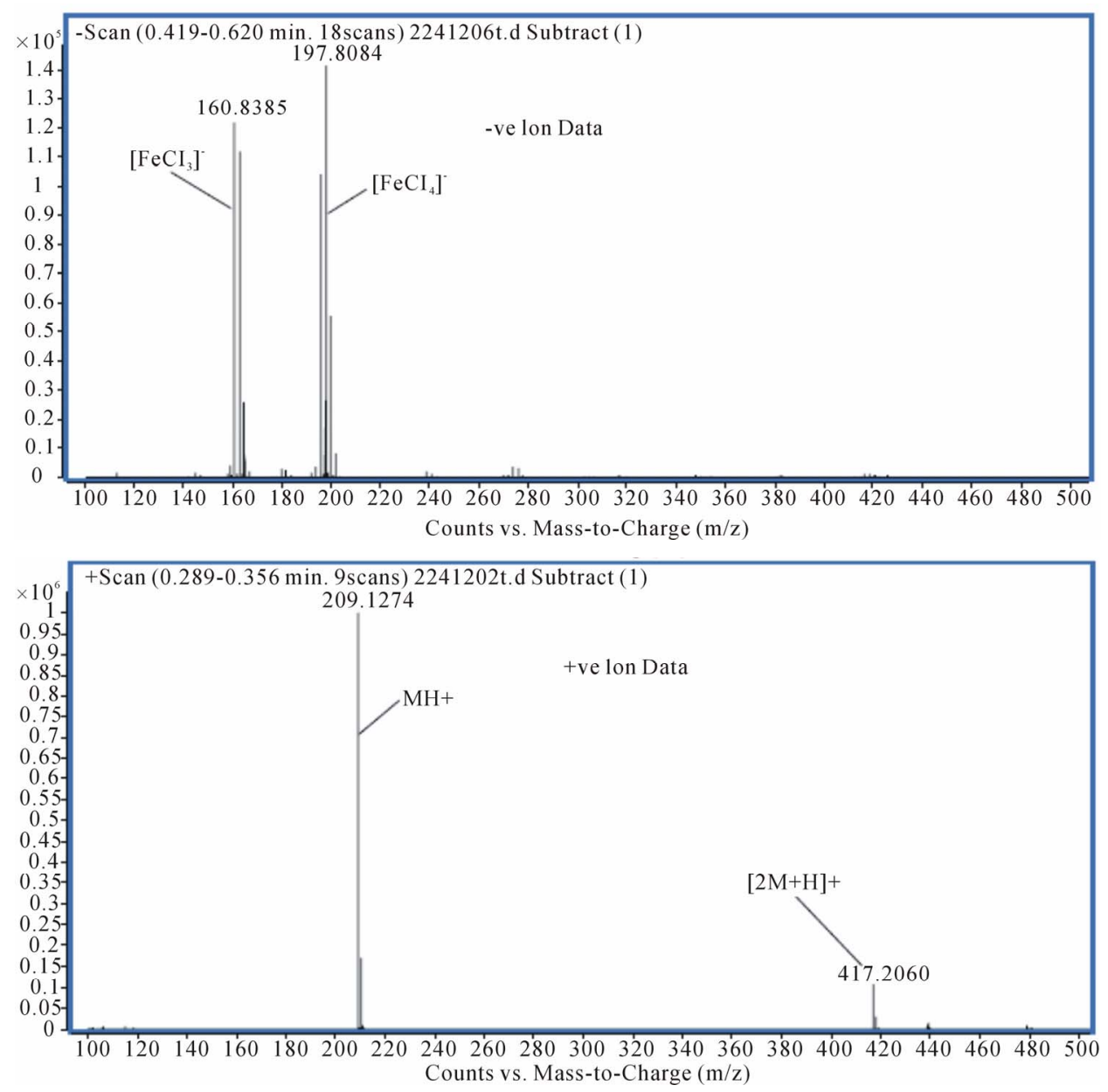

Supplemental Figure 1. Representative ESI mass spectrometry data. The ESI mass spectrum of compound 2 is shown. The ( ${ }^{\text {methyl }}$ phenH) ${ }^{+}$molecular ion is observed at $\mathrm{m} / \mathrm{z}=209$ (identified on the spectrum as $\left.\mathrm{MH}^{+}\right)$in positive ion mode, and the $\left(\mathrm{FeCl}_{4}\right)^{-}$molecular ion is observed at $\mathrm{m} / \mathrm{z}=$ 198 in the negative ion mode.

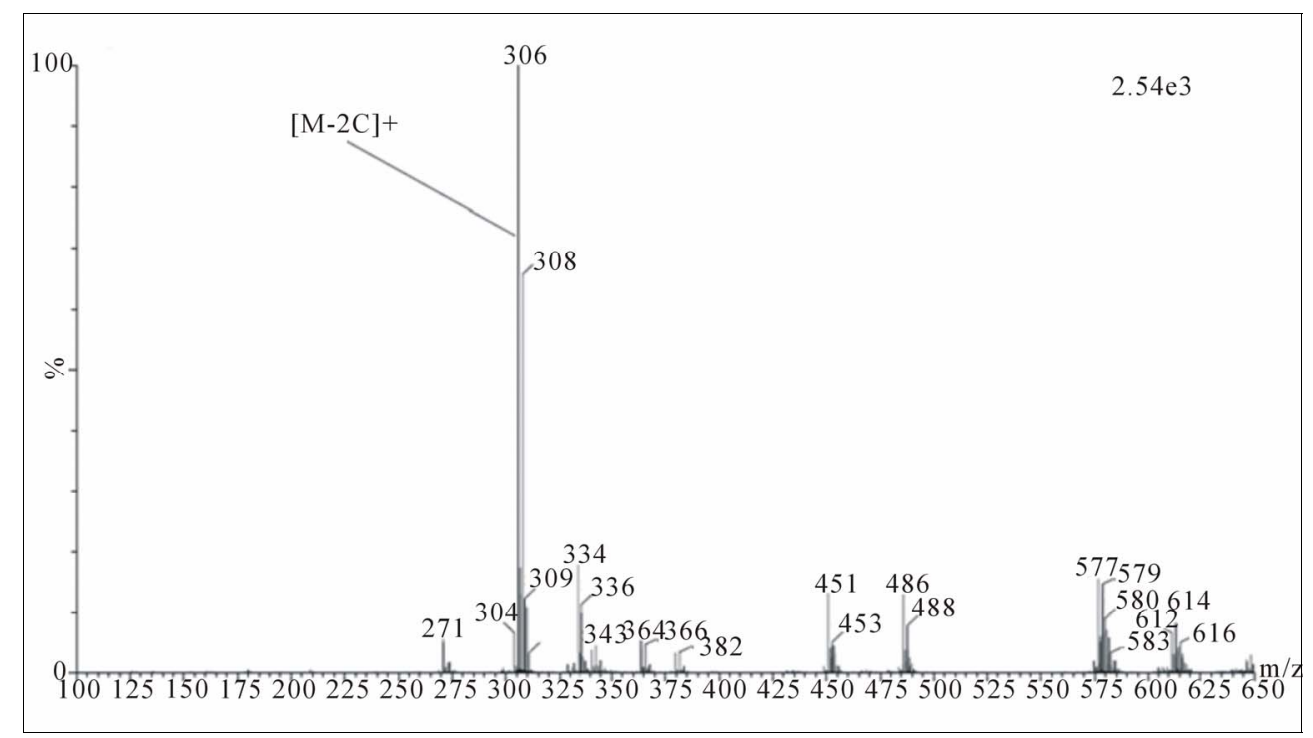

Supplemental Figure 2. LIFDI mass spectrometry analysis of compound 1 . The $\left[(\mathrm{phen}) \mathrm{FeCl}_{2}\right]^{+}$molecular ion is observed at $\mathrm{m} / \mathrm{z}=306$ (identified on the spectrum as $[\mathrm{M}-2 \mathrm{Cl}]^{+}$). 


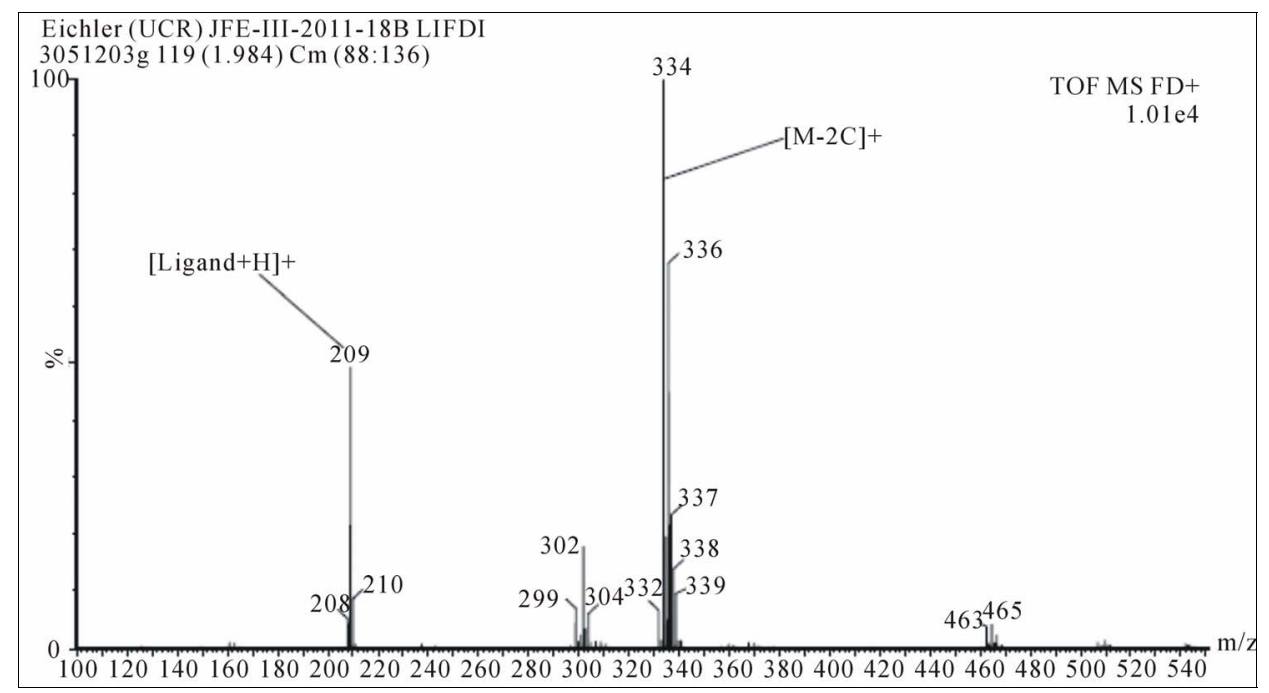

Supplemental Figure 3. LIFDI mass spectrometry analysis of compound 2. The [( ${ }^{\text {methyl }}$ phen $)$ $\left.\mathrm{FeCl}_{2}\right]^{+}$molecular ion is observed at $\mathrm{m} / \mathrm{z}=334$ (identified on the spectrum as $[\mathrm{M}-2 \mathrm{Cl}]^{+}$). 